Volume and Issues Obtainable at Center for Sustainability Research and Consultancy

Journal of Business and Social Review in Emerging Economies

ISSN: 2519-089X (E): 2519-0326

Volume 4: Issue 1June 2018

Journal homepage: www.publishing.globalcsrc.org/jbsee

\title{
Identification of Organizational Change Factors in Higher Education Institution (Cases at New Public Universities in Indonesia)
}

\author{
${ }^{1}$ Gusti Tia Ardiani, ${ }^{2}$ Adhitya Rahmat Taufiq, ${ }^{3}$ Andina Eka Mandasari
}

\author{
${ }^{1}$ Lecturer, Department of Management, Siliwangi University,Indonesia. ardiani_tia@yahoo.com \\ ${ }^{2}$ Lecturer, Department of Management, Siliwangi University, Indonesia.adhityarahmattaufiq@unsil.ac.id \\ ${ }^{3}$ Lecturer, Department of Management, Siliwangi University, Indonesia. andinaekamandasari@unsil.ac.id
}

\begin{tabular}{l}
\hline ARTICLE DETAILS \\
\hline History \\
Revised format: May 2018 \\
Available Online: June 2018 \\
\\
\hline Keywords \\
Organizational Change, New \\
Public Universities \\
\hline
\end{tabular}

JEL Classification:

D23, D29

\begin{abstract}
Purpose: The purpose of this study is to determine what factors are most contributing greatly to the change of college organizations that originally private university into the public university, the latent variable used is organizational change.

Methodology: The survey was conducted to 128 lecturers at several new public universities located on Java island by using questionnaires as the main data collection tool. The statistical tool used is Confirmatory Factor Analysis (CFA) to confirm the constructs of latent variables.

Findings: Structure, culture, and resources owned by an organization will be an important factor in shaping institutional change of higher education institution when transformed from private to public. The resource becomes one of the constructs that have the greatest role in the organizational change of higher education institutions.

Research limitations/implications: This study is limited to the proving of organizational change in the higher education institution only. In addition, it should also be investigated the direction of causality relationship by including other variables such as job satisfaction, organizational performance, and others.

Practical implications: In this study, organizational changes reflected by changes in structure, culture, and resources must always be considered by conducting regular evaluations by management to identify which factors have a positive or negative impact of changes that occur either on changes in structure, culture or resources.

Originality/value: This research is testing of constructor model of organizational change variable that uses three main factors namely structure, culture, and resources
\end{abstract}

(C) 2018 The authors, under a Creative Commons AttributionNonCommercial 4.0

Corresponding author's email address: ardiani tia@yahoo.com

Recommended citation: Ardiani, G.T., Taufiq, A.R., Mandasari, A.E. (2018). Identification of Organizational Change Factors in Higher Education Institution (Cases at New Public Universities in Indonesia). Journal of Business and Social Review in Emerging Economies, 4(1) 53-60

DOI: $10.26710 /$ jbsee.v4i1.363

\section{Introduction}

University as an educational unit carries out and implements higher education, functioning to develop 
capability and form the character and civilization of dignified nation to educate the nation, develop responsive, creative, skilled, competitive and cooperative academic society through the implementation of Tridharma Perguruan Tinggi and develop science knowledge and technology (Undang-Undang Pendidikan Tinggi: 2012). Moreover, the strategic thing that became a hot issue in higher education today is the competition of universities to be World Class University. In the meantime, to achieve this requires a change in fixing the condition of universities, and colleges must be able to act as agents of change which become the link between the source of ideas, knowledge, and technological change in accordance with the targeted community, so it can produce ideas, knowledge, and technology that is always growing and impacting in society. Government efforts in improving the quality of education in Indonesia itself began to be done on a large scale. One of the strategic steps undertaken by the government is to establish a new public university and change the status of several private universities. Currently, there are 35 institutions that are New Public Universities $(P T N B)$. This is done by the government in facing the demands of intense competition in the world of higher education which is expected to provide a more qualified and competent output in the face of global competition.

The change of status from private to public which the government does has had a considerable impact on the newly designated public university management system. Every element of the organization that is in a new public university must always follow the policies that have been governed and controlled by the state both in terms of financial, human resources and maintenance of assets that now fully belong to the state. Especially for the issue of human resource management as the organizational driving force of a new public university today must be committed to dealing with environmental changes to follow the rules of the game that has been issued by the government due to the original employment status of the foundation's employee is now transformed into a Government Employee with Work Agreement $(P P P K)$ which is also included in the State Civil Apparatus $(A S N)$.

With this change is expected to increase the lecturer's satisfaction so as to utilize his professional ability in performing his functional tasks, because the future education demands high-quality educational profession skills. The success of PTNB will depend heavily on the awareness, understanding, readiness, and ability of the lecturers in adapting to change. Changes to PTNB must always take into account and involve all existing components including lecturers. Between organizations and lecturers is a unity that has a relationship that is simultaneous and must be balanced. This means that on the one hand, lecturers should be managed within the framework of the organization's interest flow, on the other side of the organization's activities must be able to pay attention to the interests and needs expected by the lecturer.

New public universities are experiencing turmoil in the transition period of change from private to public. This change includes changes to the internal environment of the organization that requires flexible adjustment for each individual involved. This research is only conducted on lecturers and is not done on the staff of, on the grounds that the lecturer has the main duty namely Tridharma Perguruan Tinggi ie teaching, research and community service where some policies applied after the change of status deemed less accommodate the main task of lecturer, especially to conduct research and community service. Therefore, this research will discuss what factors change when a private university is transformed into public universities that will be based on environmental aspects of the organization at several universities in the island of Java. Therefore it is necessary to conduct research on the identification of organizational change factors in the higher education institution.

\section{Organizational Change of Higher Education Institution}

According to Winardi (2006: 65), organizational change is often stimulated by changes occurring in the environment that openly form the system by encompassing technological-economic-legal-politicaldemographic-ecological. While Wheelen and Hunger (2000: 8) distinguish the environment faced by organizations consisting of the external environment and internal environment. Daft (2003: 83) suggests that Elements of the internal environment are all sectors that interact directly with the organization and have a direct influence on the ability of the organization in achieving its objectives. Thus, the internal 
environment has characteristics in which interaction with the organization is directly so that the effect on the steps taken to achieve goals that are immediate. The same is also said by Robbins (2008: 226) that the internal environment is part of the environment that has direct relevance for the organization in achieving its objectives. The internal environment is part of the environment that concerns management, as it consists of critical constituencies that positively or negatively affect the effectiveness of the execution of an organization's tasks. The critical constituencies mentioned above are key factors that on one hand can be a resource for competitive advantage and on the other can be an organizational weakness.

According to Desplaces (2005), the changes that occur in organizations often bring after-effects which are always unprofitable. Organizational change is a process whereby the organization moves from its present state to the desired future to improve its organizational effectiveness. The goal is to find new ways or improve in using resources and capabilities with the aim of improving the ability of the organization in creating value and improve the desired results to stakeholders. Furthermore Wheelen and Hunger (2000: 10) state that the internal environment consists of structure, culture, resources. The internal environment needs to be analyzed to determine the strengths and weaknesses of the organization. The structure is how organizations are organized in terms of communication, authority, and workflow. Structures are often also called chains of command and graphically depicted using an organization chart. Culture is a pattern of beliefs, expectations, and values shared by members of the organization. Organizational norms typically come up with and define the acceptable behavior of members from top management to operative employees. Resources are assets that are the basic material for the production of goods and services of the organization. These assets may include a person's expertise, abilities, and managerial talents such as financial assets and factory facilities in functional areas. Thus, the elements of the internal environment have adaptive and communicative relationships in determining the agenda of analyzing actions of any changes as issues emerging within the organization itself.

Based on the above exposure, it can be formulated hypothesis and framework of research model that is as follows:

H1: Structure is a reflection of organizational change.

$\mathrm{H} 2$ : Good culture is a reflection of organizational change.

$\mathrm{H} 3$ : Resource is a reflection of organizational change.

\section{Methodology}

The object of research is organizational changes that occur in some institutions that exist on the island of Java. There are four college-shaped universities that undergo a transition status change from private to the public that is Siliwangi University Tasikmalaya, University of Tidar Magelang, UPN Veteran Yogyakarta and UPN Veteran East Java. The method used in this research is to use survey research method.

The population in this research is the lecturers from four universities of the New Public-shaped universities studied as the object of research. While the sampling technique used is purposive sampling where the sampling is based on personal consideration of the researcher (Sugiama, 2008). In this sampling, the researcher tries to find the belief in advance that the individual chosen as the sample is the right individual that is the lecturers who have experienced institutional management when they are still private so that they can feel and identify the changes that occur.

The determination of sample size in this study is based on the opinion of Hair (1995: 444) that is the survey, the minimum sample size is 100 respondents. Therefore, to improve the accuracy of research results, the sample size is taken between 100 to 200 respondents.

Data processing techniques to determine the weighting of respondents' answers is done by using the Likert scale with the magnitude of five (5) scale both positive and negative. While to know whether the structure, culture, and resource can reflect the organizational change, the method of analysis is Confirmatory Factor Analysis with second order approach which is part of SEM Analysis. SEM is a combination of two separate statistical methods that are factor analysis which developed in psychology 
and psychometrics and simultaneous equations model developed in econometrics into a comprehensive statistical method (Iman Ghozali, 2013: 4).

\section{Results}

Characteristics or identity of the respondent in this research can be grouped into several groups that are based on workplace (work unit), work period, and employment status with the number of respondents used in this research is 128 respondents. The respondent's characteristic of the work unit is dominated by Siliwangi University by $34 \%$, followed by UPN Veteran Yogyakarta that is 24\%, Tidar Magelang University is $22 \%$ and the last is East Java Veteran UPN which is $20 \%$. The working period is dominated by lecturers who have more than 20 years working period of 54\% and 10-20 years working period of 39\% and the last is less than 5 years of $7 \%$. Status of employment is the most is the status of PPPK that is equal to $69 \%$ and the remaining $31 \%$ are lecturers with civil servant status.

Description of research variables conducted to explain the results of the scores on the questionnaire used to assess the significance of research variables seen from the side responses of respondents. The calculation used in obtaining the extent to which the respondents will respond to the research variables is to use the value of interval level (NJI). Variable of organizational change in this research inform by construct variable consisting of the structure, culture, and resources. The value obtained from the analysis of respondents on the structure is 2037, the culture of 2948, and the resource of 2274 which as a whole is in good classification.

To examine the significance of structure, culture, and resources as a variable construct of Organizational Change, the Confirmatory Factor Analysis (CFA) analysis tool is used. The results of full-model data processing on Organizational Change variables through the calculation of M-plus 7.0 program are as follows:

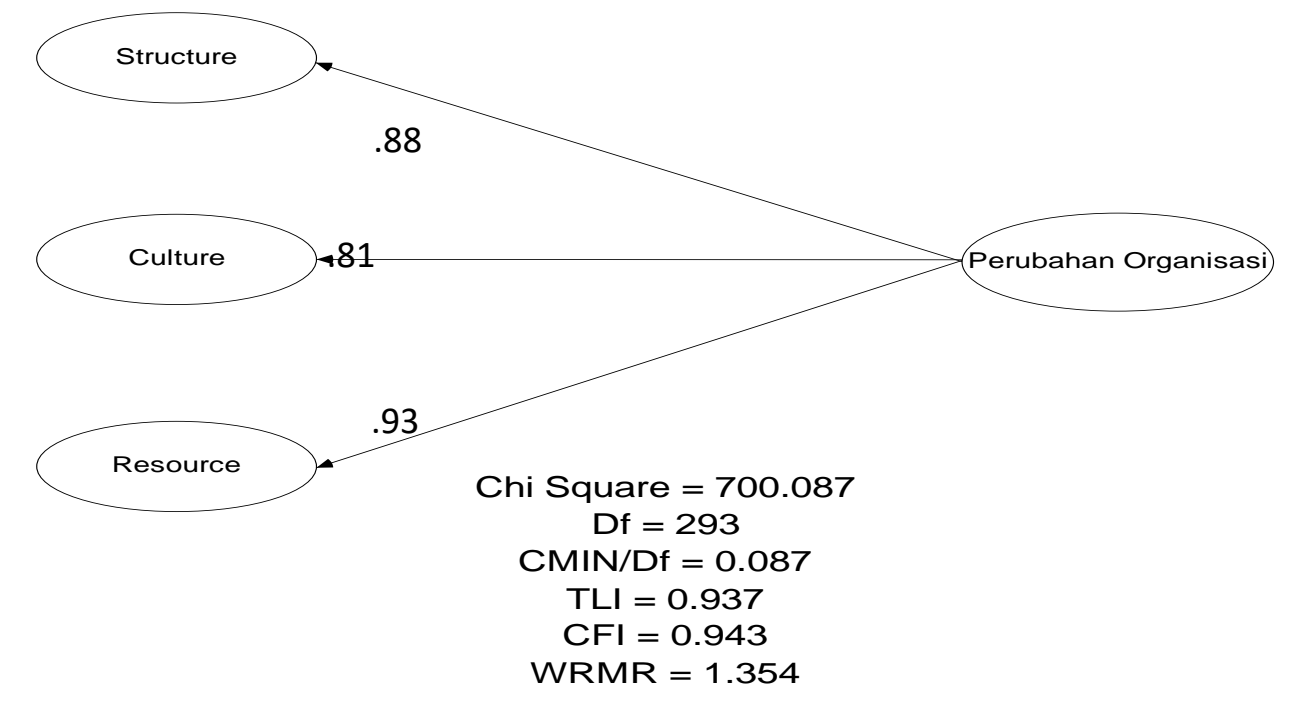

Figure 1. Path Diagram Structural Modeling

The univariate and multivariate normality of the data used in this study was tested using criteria critical ratio or CR of \pm 2.58 at the $0.01(1 \%)$ significance level. The results of this study showed that the largest CR value is \pm 2.51 with said data used in this study can be said to be normally distributed. The results of the analysis in this study yield the smallest z-score is -2.903 and the largest z-score is equal to 1.985 . In other words, the data used in this study is free of univariate outliers. In addition, the greatest distance Mahalanobis is 53.269 which is smaller than $\chi^{2}(14 ; 0.001=54,051)$, so there are no symptoms of multivariate outliers. 
Overall, the Goodness of Fit is shown in the following table:

Table 1.

Goodness-of-Fit Index

\begin{tabular}{cccc}
\hline \hline $\begin{array}{c}\text { Goodness of Fit } \\
\text { Index }\end{array}$ & Cut-Off Value & $\begin{array}{c}\text { Results of } \\
\text { Analysis }\end{array}$ & $\begin{array}{c}\text { Model } \\
\text { Evaluation }\end{array}$ \\
X $^{2}$ Chi-Square & Expected small & 700.202 & \\
DF & $\leq 2,00$ & 293 & \\
CMIN/DF & $\geq 0,95$ & 2.389 & Marginal \\
TLI & $\geq 0,95$ & 0.937 & Marginal \\
CFI & 0.943 & Marginal \\
\hline \hline
\end{tabular}

Source: data of questionnaires processed with M-plus 7.0

The table above shows that the criteria used have a value that is marginal or close to fit index, therefore this model is still acceptable. Thus, it can be stated that the suitability of the model and the data in this study result confirmation in a marginal or near-fit of factor dimensions and causality relationships between factors.

With the error rate of 5\% (0.05) and Cut-off value of 2.58. The following table presents the values of regression coefficients and C.R (Critical Ratio) as the basis of acceptance of the research hypothesis. The results of the analysis can be seen in the following table:

Tabel 2.

Standardized Regression Weight for Hypothesis Testing

\begin{tabular}{lllccc}
\hline \hline \multicolumn{2}{c}{ Variables } & & CR & p-value & Conclusion $\left(\boldsymbol{H}_{\boldsymbol{a}}\right)$ \\
\hline Organizational Change & by & Structure & 41.679 & 0,000 & Signifikan \\
Organizational Change & by & Culture & 38.612 & 0,000 & Signifikan \\
Organizational Change & by & Resource & 60.259 & 0,000 & Signifikan \\
\hline \hline
\end{tabular}

Source: data of questionnaires processed with M-plus 7.0

Hypothesis 1. which states that the structure is a reflection of organizational change received. This is indicated by the value of $\mathrm{p}=0.000$ or at a significant level of 0.05 and gives an estimated value of 0.877 . Thus, the structure variable can be the constructor of the organizational change variable.

Hypothesis 2. which states that culture is a reflection of organizational change received. This is indicated by the value of $p=0.000$ or at a significant level of 0.05 and yields an estimated value of 0.813 . Thus the culture variable can be the constructor of organizational change variable.

Hypothesis 3. which states that the resource is a reflection of organizational change received. This is indicated by the value of $p=0.000$ or at a significant level of 0.05 and gives an estimated value of 0.937 . Thus the resource variable can be the constructor of organizational change variable.

\section{Conclusions and Implications}

Structure, culture, and resources that are elements of the organization's internal environment can reflect the organizational change. Therefore, structure, culture, and resources owned by an organization will be an important factor in shaping institutional change of higher education institution when transformed from private to public. The resource becomes one of the constructs that have the greatest role in the organizational change of higher education institutions. This is due to a change in the financial resources owned by a university that initially depends on the financial capacity of the foundation, but is now funded from the state financial resources. 
This research can provide some inputs for organizers of higher education institutions that have changed the status of the private sector into the public. In this study, organizational changes reflected by changes in structure, culture, and resources must always be considered by conducting regular evaluations by management to identify which factors have a positive or negative impact of changes that occur either on changes in structure, culture or resources. This research can also provide input for academics who will conduct research on organizational change. This study is limited to the proving of organizational change in the higher education institution only, the direction for further research is to test the model of this research on other organizations. In addition, it should also be investigated the direction of causality relationship by including other variables such as job satisfaction, organizational performance, and others.

\section{References}

Azhar M. Shah, 2009, "Cultural and Organizational Change and Mergers without the Variable of Job Loss: How Job Satisfaction of Employees are Affected", Journal of Business Studies Quarterly, Vol. 1, No. 1, Pp. 26-42.

Barnard, M. \& Stoll N., 2010, "Organisational Change Management: A rapid literature review, Centre for Understanding Behaviour Change", Bristol Institute of Public Affairs. Vol. 10/01.

Barthos, Basir,2001,Manajemen Sumber Daya Manusia, Suatu pendekatan Makro, PT.Bumi Aksara,Jakarta.

Booneo, Louis E \& Kurtz, David I,2008, Pegantar Bisnis Komtemporer, Salemba Empat: Jakarta.

Boswell, W., Boudreau, J., Tichy, J., 2005, "The relationship between employee job change and job satisfaction: The honeymoon-hangover effect", Journal of Applied Psychology, 90 (2), Pp. 882-892.

Burgess, J., Julia, C., 2006, “Temporary Work and Human Resources Management: Issues, Challenges and Responses", Personnel Review; 35(2), pp:129.

Carroll, S., Flood, P, Murphy, E, Tiernan, S., 2002, "Employee reactions to flattening organizational structures", European Journal of Work Organizational Psychology, 11(9), Pp. 47-67.

Daft, Richard L., 2003, Manajemen Sumber Daya Manusia. Jakarta, Erlangga.

Graaf, de Marloes, 2012, "Job Satisfaction and Contingent Employment", Journal De Economist. 160, pp:197-218.

Gelaidan, H. M. \& Hartini Ahmad, 2013, "The Factors Affecting Employee Commitment to Change in Public Sector: Evidence from Yemen", International Business Research; Vol. 6, No. 3, Pp. 7587.

Gendron Wiyono, 2011, Merancang Penelitian Bisnis Dengan SPSS dan SmartPLS, UPP-STIM YKPN, Yogyakarta.

Gunduz, Hulya, C, Gunzel, Ayse dan Ulutas Tugce, 2012, "Effects Of Emotional Intelligence On Job Satisfaction: An empirical study On Call Center Employees", Procedia - Social and Behavioral Sciences. 58, pp:363 - 369.

Gomes, Daniel R., 2009, "Organizational Change and Job Satisfaction: The Mediating Role of Organizational Commitment”, Cominicacao e Ciencias Empresariais, exedra 1, Pp. 177-196.

Greenberg, J. \& Robert A. Baron, 2003, Behaviour in Organizations, Understanding and Managing The Human Side of Work. Third Edition. Allin and Bacon. A Division of Schuster, Massachusetts.

Pearson Prentice Hall. , 2008, Behaviors in Organizations, Ninth Edition. New Jersey:

Han, Sia Tjun, Nugroho, Agustinus., Kartika, Endo W., dan Kaihatu, Thomas., 2012, "Komitmen Afektif dalam Organisasi yang dipengaruhi Perceived Organizational Support dan Kepuasan Kerja", Jurnal Manajemen dan Kewirausahaan. 14(2), pp:109-117.

Indriantoro, Nur., Bambang Supomo, 2009, Metodologi Penelitian Bisnis untuk Akuntansi dan Manajemen, Edisi Pertama, Yogyakarta, BPFE Yogyakarta.

Jaros, S., 2010, "Commitment to Organizational Change: A Critical Review", Journal of Change Management, Vol. 10 No 1, Pp. 79-108.

Kahtani, Ali A., 2013, "Leader Charisma, Employee Organizational Commitment, and Organizational 
Change: A Proposed Theoretical Framework", International Journal of Academic Research in Business and Social Sciences, Vol. 3, No. 5, Pp. 377-399.

Kemendikbud, 2012, Undang-Undang RI No 12 Tahun 2012 Tentang Pendidikan Tinggi. (Online), (http://sipuu.setkab.go.id/PUUdoc/17624/UU0122012_Full.pdf, diakses 13 april 2014)

Nedeljkovic, M., Hadzic, O., Cerovic, S., 2012, "Organizational Changes And Job Satisfaction In The Hospitality Industry In Serbia”, UTMS Journal of Economics, Vol. 3 (2): Pp. 105-11.

Presiden RI, 2016, Peraturan Presiden RI No 10 Tahun 2016 Tentang Dosen dan Tenaga Kependidikan pada Perguruan Tinggi Negeri Baru.

Robbins, P. Stephen., 2008, Organizational Behaviour, Tenth Edition (Perilaku Organisasi, Edisi ke Sepuluh), Alih Bahasa Drs. Benyamin Molan. Jakarta, Salemba Empat.

Safitri, I.P. Wahyu. Rahardjo, Kusdi. Djudi, Moch., 2014, "Analisis Perbedaan Komitmen Organisasi Berdasarkan Status Karyawan (Studi Pada Karyawan PT. Kobexindo Tractors Tbk. Representative Office Bengkulu)", Jurnal Administrasi Bisnis. 10(1), h:215-239.

Seong J.Y., Hong D.S. \& Park. W.W., 2012, "Work status, gender, and organizational commitment among Korean workers: The mediating role of person-organization fit", Asia Pac Journal Management 29, pp:1105-1129.

Sofat, K., Kiran R. \& Kaushik S., 2015, “Organizational Change and Organizational Commitment: An Empirical Study of it Organizations in India", Global Journal of Management and Business Research, Vol. 15 Issue 6, Pp. 38-49.

Sugiyono, 2006, Statistika Untuk Penelitian, Cetakan Ketujuh, Bandung, CV. Alfabeta.

Wheelen Thomas L., dan David Hunger J. 2000, Strategic Management and Bussiness Policy, Fourth Edition, New York, Addison Wesley Publishing Company.

Wickramasinghe, Vathsala, and Chandrasekara, Rasika., 2011, "Differential effects of employment status on work-related outcomes A pilot study of permanent and casual workersin Sri Lanka", Employee Relation.33(5), pp:532-550.

Winardi, T., 2006, Manajemen Perilaku Organisasi, Jakarta: Kencana. 